\title{
Effects of High-fat Diets on Biochemical Profiles and Morpho- Quantitative Characteristics of C57BL/6 Mice Adrenal Glands
}

\author{
Efectos de la Dieta Alta en Grasa sobre el Perfil Bioquímico y las Características \\ Morfo-Cuantitativas de la Glándula Suprarrenal de Ratón C57BL/6
}

\author{
Javiera Navarrete ${ }^{1,2}$; Bélgica Vásquez ${ }^{3}$; Adriana Vasconcellos ${ }^{4}$; \\ Mariano del Sol ${ }^{2,4,5}$; Enrique Olave ${ }^{4} \&$ Cristian Sandoval ${ }^{2,6,7}$
}

NAVARRETE, J. ; VÁSQUEZ, B.; VASCONCELLOS, A.; DEL SOL, M.; OLAVE, E. \& SANDOVAL, C. Effects of high-fat diets on biochemical profiles and morpho-quantitative characteristics of C57BL/6 mice adrenal glands. Int. J. Morphol., 36(2):722-729, 2018.

SUMMARY: According to the information provided by the World Health Organization (WHO), overweight and obesity are the fifth leading causes of death in the world. Due to the alarming increase of this disorder in recent years, studies have been carried out to evidence harmful effects on human or animal tissues. Our objective was to evaluate the morphological and physiological changes of C57BL/6 mice adrenal glands (AGs), associated with high fat diets (HFDs), we used 14 male mice, 5 months old, fed for 14 weeks according to two diets. The standard chow group (SC) was fed AIN-93M and the high fat group (HF) was fed AIN-93M-HF. At the end of the experiment, biometric analysis was performed and euthanasia was performed. Blood was then extracted for biochemical analysis and AGs were processed for mesoscopic, histological, morphometric and stereological studies. We used Student's $t$-test ( $\mathrm{p}<0.05$ ) for statistical analysis. SC group showed a lower weight $(29.67 \pm 1.28 \mathrm{~g})$ with respect to the HF group (38.46 $\pm 4.68 \mathrm{~g}, \mathrm{p}=0.002)$. COL-T, HDL-C, TG and CORT analysis revealed differences between SC group and HF ( $\mathrm{s} \leq 0.001)$. Focally, in the fasciculate area, there was an increase in the core-cytoplasm ratio and a greater lipid vacuole presence and size. There was a significant reduction $(\mathrm{p}=0.001)$ in $\mathrm{V}_{\mathrm{vfas}}=7.365 \pm 3.326 \%$ of the HF group fasciculate area compared to SC group $\left(\mathrm{V}_{\mathrm{vfas}}=9.619 \pm 4.548 \%\right)$. Obesity induced by HF diets affects adrenal gland physiology and morphology of mice. Our results suggest that both the percentage of fat as well as the time of administration of the diet, produce a diurnal reduction of corticosterone, which could be due to an increase in the metabolic clearance of this hormone and not to the inhibition of the Hypothalamus-Pituitary-Adrenal (HPA) axis.

KEY WORDS: Adrenal gland; Morphometry; Stereology; High fat diet; Corticosterone.

\section{INTRODUCTION}

Obesity is a chronic disease that occurs when energy intake, expressed as Kcal, exceeds energy expenditure (Bray, 2004). Obesity causes are multiple, and include factors such as genetic inheritance, age, type or lifestyle, physical activity, among others (Kopelman, 2000). Recent data reported by the World Health Organization indicate that between 1975 and 2016, the prevalence of obesity has almost tripled, favoring an increased risk of non-communicable diseases such as diabetes, musculoskeletal disorders, the metabolic syndrome, cardiovascular diseases and some cancers (WHO, 2017).
In this sense, research has shown that obesity in humans and animals induced by $\mathrm{HFD}_{\text {s }}$ has detrimental effects on tissues and organs that leads to endocrine complications. Chakraborty et al. (2016) suggest that the administration of HFDs produces changes in the morphology and size of adipocytes and pancreatic islets, producing chronic insulin and leptin releases. Other authors have pointed out that HFDs produces morphometric and/or metabolic changes in the kidney (Altunkaynak et al., 2008), liver (Bravo et al., 2011), ileum (Navarrete et al., 2015) and adrenal glands (Auvinen et al., 2012; Mokrani et al., 2012). In fact, morphofunctional studies

\footnotetext{
${ }^{1}$ Universidad Autónoma de Chile, Temuco, Chile.

${ }^{2}$ Programa de Doctorado en Ciencias Morfológicas, Facultad de Medicina, Universidad de La Frontera, Temuco, Chile.

${ }^{3}$ Facultad de Ciencias de la Salud, Universidad de Tarapacá, Arica, Chile.

${ }^{4}$ Departamento de Ciencias Básicas, Facultad de Medicina, Universidad de La Frontera, Temuco, Chile.

${ }^{5}$ Centro de Excelencia en Estudios Morfológicos y Quirúrgicos (CEMyQ), Universidad de La Frontera, Temuco, Chile

${ }^{6}$ Centro de Investigación en Morfología Aplicada (CIMA), Facultad de Odontología, Universidad de La Frontera, Temuco, Chile.

${ }^{7}$ CONICYT-PCHA/Doctorado Nacional/2015-21150991, Santiago, Chile.

Funding: Universidad de La Frontera, Proyecto DIUFRO N ${ }^{\circ}$ DI16-0111.
} 
show that $\mathrm{HFD}_{\mathrm{s}}$ produce a significant increase in plasma cortisol levels and adrenal gland sizes (Auvinen et al.; Mokrani et al.); morphological changes characterized by an increase in the adrenal cortex due to hyplerplasia and/or hypertrophy of fasciculate area cells, with or without changes in the glomerular or medullary zone (Mokrani et al.; Swierczynska et al., 2015).

In human and animal models, it has been shown that cortisol promotes the accumulation of fat cells and weight gain (Björntorp \& Rosmond, 2000; Björntorp, 2001; Peckett et al., 2011), which implies the functioning of the Hypothalamus-Pituitary-Adrenal (HPA) axis in the etiology of obesity. However, the data are inconsistent, possibly due to the methodological differences between the studies (Bose et al., 2009).

Activity on the HPA axis is typically indicative of a response to stress or rhythmicity diurnal, however factors such as food intake can also lead to cortisol secretion (Rosmond $e t$ al., 2000). Activation of the HPA axis begins in the hypothalamus, with the release of corticotropin-releasing hormone $(\mathrm{CRH})$. This stimulates the release of the adrenocorticotropic hormone $(\mathrm{ACTH})$ from the anterior pituitary gland, which in turn circulates through the bloodstream to the adrenal cortex, signaling the adrenal glands to secrete cortisol, in humans and corticosterone in rodents (Kyrou \& Tsigos, 2009).

In addition to these mechanisms of activation of the HPA axis that culminate with the release of cortisol, studies in rodents have shown that the activity and metabolism of cortisol also come from metabolic sources of adipocytes, such as abdominal and subcutaneous adipose tissue with a upregulation in cortisol production due to an increased expression of $11 \mathrm{~b}-$ hydroxysteroid dehydrogenase type $1(11 \beta-H S D-1)$ that converts inactive cortisone to active cortisol, promoting visceral obesity and characteristics indicative of metabolic syndrome (diabetes, dyslipidemia, hypertension) (Livingstone et al., 2000). Consistent with the above findings, in humans, the expression of $11 \beta$-HSD-1 is significantly higher in the subcutaneous and visceral adipose tissues of obese versus nonobese individuals (Desbriere et al., 2006; Paulsen et al., 2007). This general pattern of overexpression of $11 \beta$-HSD- 1 in adipose tissue supports the notion that deregulation in the activity of non-adrenal cortisol leads to a subsequentderegulation of the HPA axis as a compensating mechanism that may influence the overall activity of cortisol (Rask et al., 2002).

The literature, to date, is not conclusive, which could be due to the differential effects of generalized obesity against abdominal obesity or modulators such as sex, sex hormones and chronic stress (Incollingo Rodriguez et al., 2015).
On the other hand, there is a great variety of studies that report findings that relate to obesity, the HPA axis, adipose tissue and cortisol. However, fewer researches address the morphological effects of AGs in this context. Therefore, our objective was to evaluate the morpho-physiological changes of the AG of C57BL/6 mice fed with HFD.

\section{MATERIAL AND METHOD}

Animals: We used 14 clinically healthy male C57BL/6 fivemonth-old mice (Mus musculus). The study was conducted in accordance with the Guide for Care and Use of Laboratory Animals (National Research Council (U. S.) Committee for the Update of the Guide for the Care and Use of Laboratory Animals; 2011). The experimental protocol was approved by the Scientific Ethics Committee of the Universidad de La Frontera (Project N 021/2016).

Diet: At 5 months of age, the mice were randomly divided into two groups: standard chow group (SC) and high-fat diet group (HF). SC group animals were fed a standard rodent diet composed of $10 \%$ fat according to AIN-93M. The HF group was fed a diet containing $42 \%$ fat (AIN-93M-HF) (Reeves et al., 1993).

Diets were prepared by PRAGSOLUÇÕES Biociências (www.pragsolucoes.com.br, Jau, SP, Brazil). Diets were stored at $-20^{\circ} \mathrm{C}$ for conservation throughout the study. Diet composition is specified in Table I, and the percentage of macronutrients in Table II. Vitamin and mineral contents of both diets were identical.

Table I. Diet compositions according to the American Institute of Nutritional. Recommendation for Laboratory Rodents.

\begin{tabular}{lcc}
\hline Ingredients $(\mathrm{g} / \mathrm{Kg})$ & AIN-93M & AIN-93M-HF \\
\hline Casein & 140 & 190 \\
Cornmeal & 620 & 250 \\
Sucrose & 100 & 100 \\
Soy oil & 40 & 40 \\
Shortening & - & 320 \\
Fiber & 50 & 50 \\
Vitamin mix* & 10 & 10 \\
Mineral mix* & 35 & 35 \\
Cystine & 1.8 & 1.8 \\
Antioxidants & 0.008 & 0.008 \\
Colina & 2.5 & 2.5 \\
Total grams & 1000 & 1000 \\
\hline
\end{tabular}

AIN-93M (American Institute of Nutrition and diet maintenance for adult rodents).

AIN-93M-HF (American Institute of Nutrition and high-fat diets).

*Vitamin and mineral mixtures were in accordance with AIN-93 recommendations. 
Table II. Total percentage of macronutrients according to the American Institute of Nutritional. Recommendation for Laboratory Rodents.

\begin{tabular}{lcc}
\hline Macronutrients & AIN-93M & AIN-93M-HF \\
\hline Sucrose (\%) & 8 & 8 \\
Carbohydrates (\%) & 76 & 44 \\
Proteins (\%) & 14 & 14 \\
Lipids (\%) & 10 & 42 \\
Energy content (Kcal/Kg) & 3,870 & 5,407 \\
\hline
\end{tabular}

AIN-93M (American Institute of Nutrition and diet maintenance for adult rodents).

AIN-93M-HF (American Institute of Nutrition and high-fat diets).

Animals were subjected to a period of adaptation to the new environment, for approximately 4 weeks, and then the respective diets and water (ad libitum) were provided, for a total of 12 weeks. Food was removed and replaced with fresh food every two days, as to avoid contamination and fat oxidation.

Biometry: The body weight of each animal was recorded at the beginning of the study and then every seven days until completing the experiment at the end of 12 weeks.

Euthanasia: At the end of the experiment, the animals were fasted for 6 hours for euthanasia with sodium pentobarbital. Blood samples were then obtained from the right atriums. Samples were centrifuged (3500 rpm for $15 \mathrm{~min}$ ) at $4{ }^{\circ} \mathrm{C}$, keeping the serum at $-80^{\circ} \mathrm{C}$ until analysis. Subsequently, the AGs of each animal were removed using ad hoc surgical instruments and dissected mesoscopically under a 10X magnifying glass (Motic ${ }^{\circledR}$ SMZ-171).

Biochemical analysis: Lipid profiles were determined for members of each group: COL-T (CHOLESTEROL liquicolor, Human, Germany), TG (TRIGLYCERIDES liquicolormono, Human, Germany) through a colorimetric enzymatic method (HDL-C), and high density lipoproteins through a colorimetric kinetic method (HDL CHOLESTEROL liquicolor, Human, Germany). Each determination was made according to the manufacturer instructions.

Serum CORT levels were determined using a mousespecific ELISA kit obtained from Invitrogen (Thermo Fisher Scientific, Inc. Waltham, Massachusetts, USA) with a specificity of $100 \%$ for mouse CORT. Samples were analyzed in triplicate and entered into GraphPadPrism 2.0 software to calculate the concentrations of each sample.

Mesoscopic analysis: AGs weights were recorded with an A \& D Orion HR 120 analytical balance $(0.1 \mathrm{mg}$ to $120 \mathrm{~g}$ ), while width, length and thickness were recorded with a Stainless steel Hardened digital pachymeter $(0-150 \mathrm{~mm})$.
For light microscopy analysis, glands were fixed in $10 \%$ buffered formalin with $7.4 \mathrm{pH}$ for 24 hours and processed following the conventional inclusion protocol in Paraplast Plus (Sigma-Aldrich Co, St. Louis, MO, USA).

The AGsM/BM index was calculated like adrenal glands mass (AGsM) divided by body mass (BM) in each animal.

Histological, morphometric and stereological analysis. A gland from each animal was randomly selected for analysis. From each gland, 5 cuts were selected, which were then stained with $\mathrm{H} \& \mathrm{E}$, for histological, morphometric and stereological analysis. Plates were observed in a stereological optical microscope (Leica ${ }^{\circledR}$ DM2000 LED), with a motorized stage on the $\mathrm{Z}$ axis $\left(\right.$ Prior $\left.^{\circledR}\right)$ and a HD digital camera $\left(\right.$ Leica $^{\circledR}$ $\mathrm{MC} 170 \mathrm{HD})$. Images were projected on a DELL INSPIRON 14 Notebook.

For the morphometric analysis of nuclei from fasciculate zone, the circular shape of this structure was considered for mean diameter determinations based on measurements of the largest and smallest diameter on the equatorial plane. Morphometric measurements were taken using ImageJ Software (National Institutes of Health, Bethesda, Maryland, USA), evaluating a total of 150 nuclei per group.

For stereological analysis, one nucleus was considered to represent one cell. We sampled all fasciculate zone nuclei only in the look-up plane when they were partly or totally inside the frame and did not intersect the left or inferior exclusion edges or their extensions (Gundersen, 1977). $Q_{A}$ is the number of the cellular nuclei in the testarea appearing in an unbiased counting frame of $36.36 \mathrm{x} \mathrm{d}^{2}$ on the one-slice plane: "disector" is the volume of the disector, that is, the product of the disector thickness $(\mathrm{t})$ multiplied by the test-area $\left(\mathrm{A}_{\mathrm{T}}\right)$ and $\mathrm{d}$ is a line of known length. A test system consisting of 42 test points $\left(\mathrm{P}_{\mathrm{T}}\right)$ was assembled on the monitor. The volume density of AGs fasciculate zones $\left(\mathrm{V}_{\mathrm{Vfas}}\right)$ was then estimated as the ratio of the points hitting the cellular nuclei from each fasciculate zone $\left(\mathrm{P}_{\mathrm{p}}\right)$ compared to the number of test points (Mandarim-de-Lacerda, 1995): $\mathrm{V}_{\mathrm{Vfas}}=\mathrm{V}_{\mathrm{V}}$ [fasciculate zone] $/ \mathrm{P}_{\mathrm{T}}$. This method was performed with Paraplast embedded material stained with H\&E.

Statistical analysis. was performed using IBM SPSS Statistic $20^{\circ}$ software, and the Kolmogorov-Smirnov test (normality analysis of the data) or Shapiro-Wilk test (homoscedasticity analysis), for verification of assumptions. The Student's t-test was used for analysis of differences between groups. A $p<0.05$ value was considered significant $(*)$ and a $p<0.025$ value as very significant $(* *)$. 


\section{RESULTS}

Biometry. At the end of the study, the mean weight of the mice in SC group was $29.67 \pm 1.28 \mathrm{~g}$, while that in the HF group was $38.46 \pm 4.68 \mathrm{~g}(\mathrm{p}=0.002)$. In addition, the weight gains of the $\mathrm{HF}$ group $(8.63 \pm 2.98 \mathrm{~g})$ was significantly higher $(\mathrm{p}=0.009)$, compared to SC group (3.82 \pm 2.54 g) (Fig. 1). Mice of HF group showed higher intra-abdominal fat in relation to SC group (Fig. 2).

Biochemical analysis. The biochemical results are shown in Table III. Lipid profiles of HF mice were higher in both COLT-T, TG and HDL-C, compared to SC group mice. A decrease in CORT plasma levels was found in the HF group, with respect to SC group. All analyzes showed significant differences between groups $(\mathrm{p}<0.001)$.

Mesoscopic analysis. Mesoscopic analysis showed significant differences in AGs weights and sizes. It was determined that the mean AGs weight of the HF group $(0.0032 \pm 0.0009 \mathrm{~g})$ was higher with respect to group C $(0.0021 \pm 0.0003 \mathrm{~g})(\mathrm{p}=0.01)$. Likewise, AGs of HF mice $(2.19 \pm 0.17 \mathrm{~mm})$ were longer compared to SC mice $(1.83 \pm 0.28 \mathrm{~mm})(\mathrm{p}=0.01)$. Finally, the mean AGsM/BM index of the HF group $(0.0083 \pm 0.0023 \mathrm{~g})$ was higher with respect to $\mathrm{SC}$ group $(0.0073 \pm 0.0016 \mathrm{~g})(\mathrm{p}=0.404)$.

Histological analysis. The outermost glomerulosa zone in the SC group adrenal cortex was thin and consisted of small glomerularly arranged cells. Below the glomerulosa zone, there is the fasciculate zone, which makes up most of the adrenal cortex. Cells were larger than those of the glomerular zone, with central arrangement spherical nuclei and acidophilic cytoplasm, vacuolated with abundant drops of lipids. They formed cellular columns directed towards the adrenal medulla, separated from each other by sinusoids (Fig. 3). Deeper reticular zones were not clearly distinguishable in the mice. These zones were composed of small polygonal cells arranged in unicellular cords in the form of a network, separated by blood capillaries. They also had greater cell densities than cells from neighboring areas and cytoplasmic vacuoles were not evident.

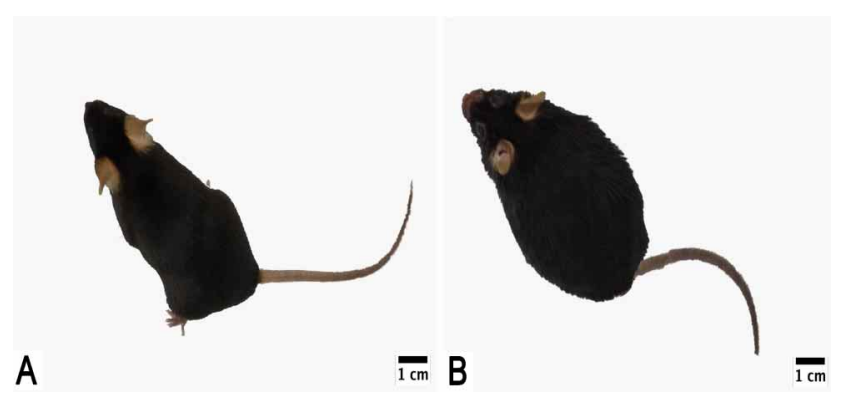

Fig. 1. Photography of males C57BL/6 mice fed with standard chow (A) or high-fat diet (B).
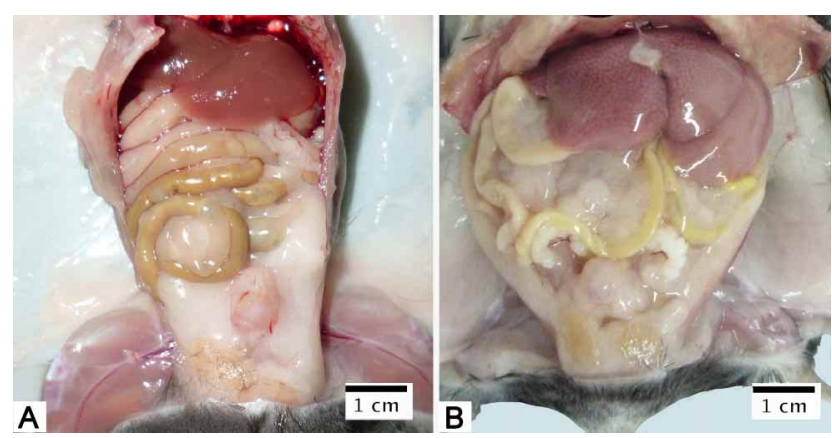

Fig. 2. Open view of the abdomen of representative animals. Intraabdominal fat of the SC group (A) and the HF group (B).

The adrenal medulla of SC group, and is completely surrounded by the cortex. It contains two populations of parenchymal cells, chromaffin cells and sympathetic ganglion cells. Chromaffin cells were the most abundant, characterized by being arranged in groups or short cords. Nuclei were located centrally and presented an eosinophilic cytoplasm with abundant small granules. Less abundant ganglion cells were arranged randomly within the marrow. They were larger than the chromaffin cells, with pale central nuclei and cytoplasm due to granule absence.

The fasciculate area was thicker and the capsule and glomerular area were found conserved to the adrenal cortex in HF group. Congestion was observed at the cortex interface with cord and sinusoidal capillary congestion at the cortical level. Likewise, in the fasciculate area, an increase in the nucleus-cytoplasm relationship was observed, showing

Table III. Biochemical analysis of male C57BL/6 mice subjected to high-fat diets.

\begin{tabular}{lccc}
\hline Parameters & \multicolumn{2}{c}{ Mean SD } & $p$ \\
& $2.193 \pm 0.244$ & $3.882 \pm 0.472$ & $<0.001$ \\
COL-T $(\mathrm{mmol} / \mathrm{L})$ & $1.839 \pm 0.330$ & $2.821 \pm 0.998$ & 0.001 \\
HDL-C $(\mathrm{mmol} / \mathrm{L})$ & $1.890 \pm 0.098$ & $2.111 \pm 0.249$ & $<0.001$ \\
TG $(\mathrm{mmol} / \mathrm{L})$ & $18.168 \pm 1.401$ & $10.220 \pm 1.742$ & $<0.001$ \\
CORT $(\mathrm{ng} / \mathrm{mL})$ & & &
\end{tabular}


a greater presence and size of lipid vacuoles. In addition, fasciculate architectures were lost focally in the deepest cortex areas, with cells forming groups (Fig. 4).

Histologically, the adrenal medulla of HF group retained the same characteristics as the SC group. However, it is congestive.
Morphometric and stereological analysis. The mean diameter of nuclei from fasciculate area cells in the HF group was significantly higher $(5.981 \pm 0.73 \mathrm{~mm}, \mathrm{p}=0.001)$ with respect to SC group $(5.578 \pm 0.5139 \mathrm{~mm})$. Stereological analysis reflected a decrease in $\mathrm{N}_{\mathrm{V}}$ and $\mathrm{V}_{\mathrm{v}}$ of the fasciculate area of AGs of HF group (p<0.001) (Fig. 5).

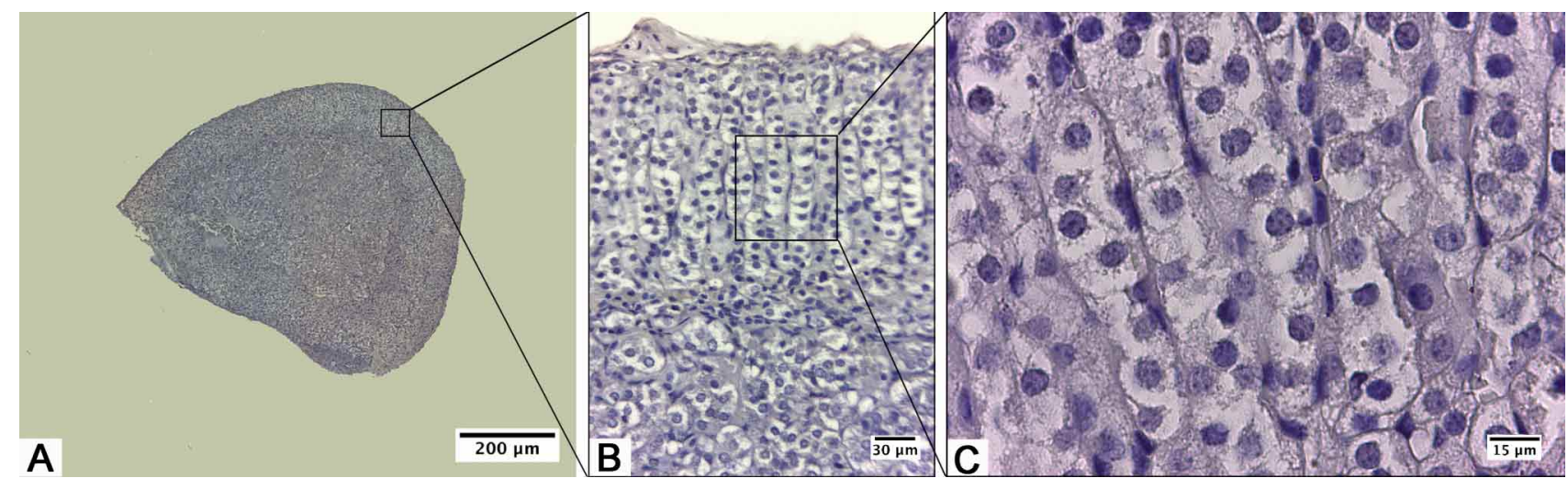

Fig. 3. Adrenal glands of C57BL/6 mice fed with standard diets (SC group). A, B and C: Fasciculate area of the adrenal cortex under different magnifications. H\&E stain.
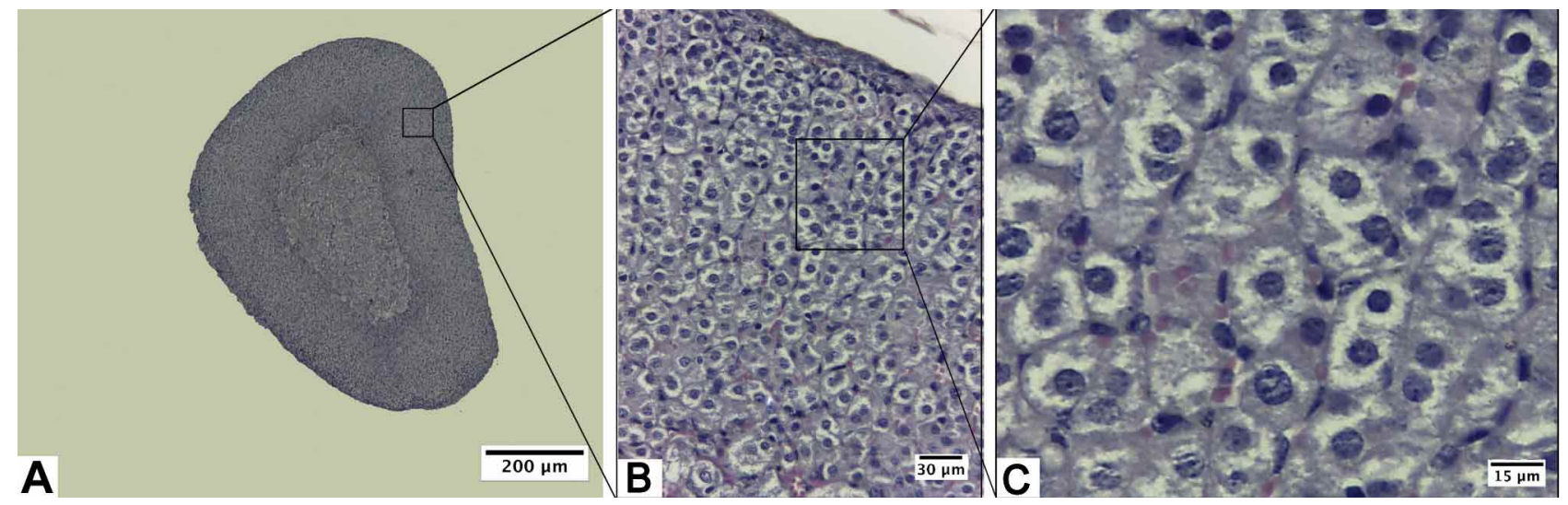

Fig. 4. Adrenal glands of C57BL/6 mice fed with high-fat diet (HF Group). A, B and C: Fasciculate area of the adrenal cortex under different magnifications. H\&E stain.
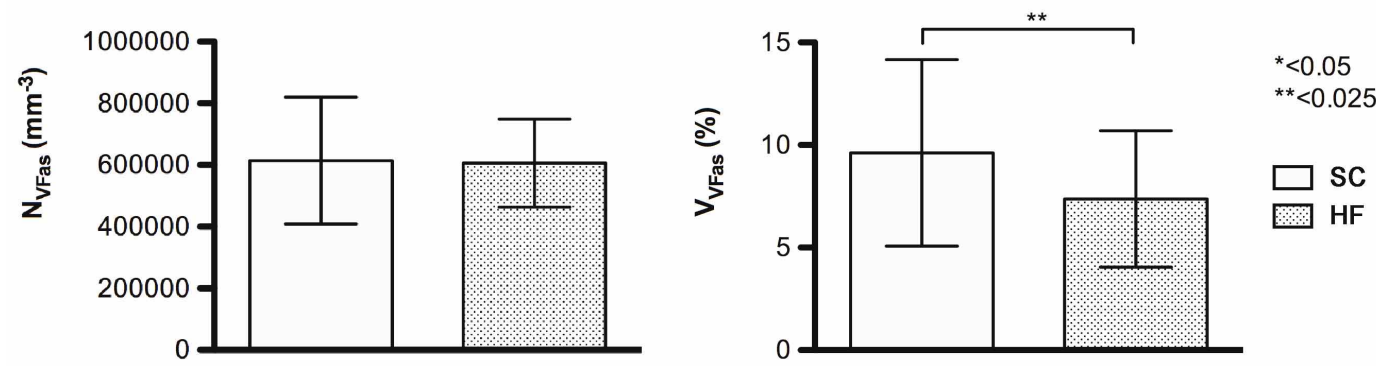

Fig. 5. Stereological and statistical analysis of the fasciculate area of the adrenal glands of male C57BL/6 mice fed with standard chow (SC group) or high-fat diet (HF group). 
NAVARRETE, J. ; VÁSQUEZ, B.; VASCONCELLOS, A.; DEL SOL, M.; OLAVE, E. \& SANDOVAL, C. Effects of high-fat diets on biochemical profiles and morpho-quantitative characteristics of C57BL/6 mice adrenal glands. Int. J. Morphol., 36(2):722-729, 2018.

\section{DISCUSSION}

According to previous studies, HFD produce significant weight gain and total body fat (Yang et al., 2007; Aslam et al., 2010; Kim et al., 2012; Navarrete et al.). In our study, HF group mice presented a mean weight and greater weight gain, compared to SC group mice $(\mathrm{p}<0.025)$. This weight gain was mainly related to body size and fat deposits.

Several results have been observed in plasmatic lipid analysis of animals fed with HFD. In this sense, studies in mice presented a significant increase in COLT-T and TG (Kim et al.), while others showed significant changes only in COL-T (Samuelsson et al., 2008; Navarrete et al.) or TG (Yang et al.). Likewise, other investigations have not reported significant differences in the serum analysis of lipid profiles compared to their respective controls (Jiang et al., 2005; Ble-Castillo et al., 2012). Our results showed a significant increase in plasmatic levels of COLT-T, HDL-C and TG in HF group mice, compared to the SC group mice ( $<<0.001$, $\mathrm{p}=0.001$ and $\mathrm{p}<0.001$, respectively). These discrepancies may be related to the type of sample used, the variability of the models, the nature and percentage of lipids, as well as the form and time of diet administration, among other factors (Jiang et al.; Navarrete et al.).

Corticosterone plasmatic levels show something similar to that indicated above. Pratchayasakul et al. (2011) and Swierczynska et al., pointed that hyperlipideal diets can cause increases in plasma levels of this hormone, while recent studies included our research, described a reduction in diurnal plasma concentrations of this hormone (Auvinen et al.). Meanwhile, other authors like Herberg \& Kley (1975), established that HFD have no effect on corticosterone levels. The discrepancies of these evaluations can also be observed in different types of samples. Thus, Mokrani et al., did not find an increase in plasma cortisol levels in obese rabbits, although they did observe a significant increase of this hormone in AGs and periadrenal fat.

Mesoscopic analysis showed higher values of mean length of AGs in the HF group mice respect to the SC group $(\mathrm{p}=0.01)$. The $\mathrm{AGsM} / \mathrm{BM}$ index was also higher, although without significant differences $(\mathrm{p}=0.404)$. Although our results showed a tendency to increase these parameters, they were not as evident as those observed by Swierczynska et al. who administered a diet with $60 \% \mathrm{Kcal}$ of fat for a longer time than ours ( 18 weeks). The authors observed that the adrenal cortex was $37 \%$ longer and the adrenal mass had a strong correlation with the weight gain of the animal. They pointed these results could be by the larger thickness of the fasciculate area, since these changes were not observed in the glomerular area. Likewise, they reported a greater number of nuclei in the fasciculate area, concluding the increase in gland size could be caused by cellular hyperplasia. Our results suggest that greater weights $(0.0032 \pm 0.0009 \mathrm{~g})$ and lengths $(2.19 \pm 0.17 \mathrm{~mm})$ of AGs in mice fed with HFDs could be caused for an increased thickness of the fasciculate zone. However, histological and morpho-quantitative analyzes showed this increase was mainly related to a greater nucleus-cytoplasm ratio, favored by the greater presence and quantity of lipid vacuoles and not by cellular hyperplasia, since there was no significant difference in the $\mathrm{N}_{\mathrm{v}}$ of the fasciculate area between the SC and $\mathrm{HF}$ groups and, the $\mathrm{V}_{\mathrm{v}}$ were lower $(\mathrm{p}<0.001)$ in HF group than in $\mathrm{SC}$ group.

As noted above, glucocorticoid levels in obesity show different results, however, many studies support the idea that exits an increase in the overall activity of cortisol (Stomby et al., 2014). Supporting this, the excretion of glucocorticoid metabolites in the urine is elevated in obese people (Andrew et al., 1998). In addition, obesity has been associated with negative suppression of the HPA axis (by dexamethasone suppression tests) in some (Ljung et al., 1996), but not in all studies (Glass et al., 1981), and with increased stimulation of cortisol production by ACTH (Hautanen \& Adlercreutz, 2010). However, circulating cortisol levels are normal or slightly decreased in the morning in obese individuals (Kumari et al., 2010). This combination of increased urinary excretion of cortisol metabolites with a hyperdynamic HPA axis and normal cortisol levels is likely to be explained by the increased peripheral metabolic clearance of cortisol. In fact, increased cortisol clearance has been documented repeatedly in obesity (Strain et al., 1980; Lottenberg et al., 1998; Stimson et al., 2009, 2011). The aforementioned could explain the results of the studies carried out by Auvinen et al. and ours, regarding the decrease in plasma levels of diurnal corticosterone in mice fed with HFDs.

Obesity induced by HFDs changes adrenal gland morphology in mice, reflected in increased mass and length. The observed are mainly related to a thicker fasciculate zone whose cells show an increase in the nucleus-cytoplasm ratio. These morphological changes suggest greater activity of the gland. The percentage of fat used, as well as the time of administration of this diet, decreased the plasma levels of corticosterone diurnal, however, this could be due to an increase in the peripheral metabolic clearance of the hormone and not to an inhibition of the HPA axis. Future investigations should address signaling pathways affected by HFDs and their importance in hormone regulation at the hypothalamus-hypophysisadrenal gland level. 
NAVARRETE, J.; VÁSQUEZ, B.; VASCONCELLOS,A.; DEL SOL, M.; OLAVE, E. \& SANDOVAL, C. Efectos de la dieta alta en grasa sobre el perfil bioquímico y las características morfo-cuantitativas de la glándula suprarrenal de ratón C57BL/6. Int. J. Morphol., 36(2):722-729, 2018.

RESUMEN: De acuerdo a la información entregada por la OMS, el sobrepeso y la obesidad son el quinto factor principal de riesgo de muerte en el mundo. Debido al aumento alarmante de este trastorno en los últimos años, estudios evidencian efectos perjudiciales sobre tejidos humanos y animales. Por lo tanto, nuestro objetivo fue evaluar los cambios morfo-fisiológicos de la glándula suprarrenal de ratones C57BL/6 asociado a dietas altas en grasas. Utilizamos 14 ratones machos, de 5 meses, alimentados por 14 semanas con dos dietas. Grupo dieta estándar (SC), alimentados con AIN-93M y grupo alto en grasa (HF), alimentado con AIN93M-HF. Al finalizar el experimento, se realizó el análisis biométrico y se efectuó la eutanasia. Posteriormente, se extrajo sangre para el análisis bioquímico y cada glándula suprarrenal fue procesada para el estudio mesoscópico, histológico, morfométrico y estereológico. Para el análisis estadístico se utilizó la prueba t de Student $(\mathrm{p}<0,05)$. El grupo SC mostró un menor peso $(29,67 \pm 1,28$ g) respecto al grupo $\mathrm{HF}(38,46 \pm 4,68 \mathrm{~g} ; \mathrm{p}=0,002)$. El análisis del COL-T, HDL-C, TG y CORT reveló diferencias entre el grupo SC y HF $(p \leq 0,001)$. En la zona fasciculada, focalmente, se observó aumento en la relación núcleo-citoplasma y, mayor presencia y tamaño de vacuolas lipídicas. Hubo una reducción significativa $(\mathrm{p}=0,001)$ en $\mathrm{V}_{\text {vfas }}=7,365 \pm 3,326 \%$ de la zona fasciculada del grupo $\mathrm{HF}$, en comparación al grupo $\mathrm{SC}\left(\mathrm{V}_{\mathrm{vfa}}=9,619 \pm 4,548 \%\right)$. La obesidad inducida por la dieta HF afecta la fisiología y morfología de la glándula suprarrenal de ratones alimentados con dietas altas en grasas. Nuestros resultados sugieren que tanto el porcentaje de grasa, así como el tiempo de administración de la dieta, producen una reducción diurna de la corticosterona, lo que podría ser debido a un aumento en el aclaramiento metabólico de esta hormona y no a la inhibición del eje Hipotálamo-Hipófisis-Adrenal.

PALABRAS CLAVE: Glándula suprarrenal; Morfometría; Estereología; Dieta alta en grasas; Corticosterona.

\section{REFERENCES}

Altunkaynak, M. E.; Ozbek, E.; Altunkaynak, B. Z.; Can, I.; Unal, D. \& Unal, B. The effects of high-fat diet on the renal structure and morphometric parametric of kidneys in rats. J. Anat., 212(6):845-52, 2008.

Andrew, R.; Phillips, D. I. \& Walker, B. R. Obesity and gender influence cortisol secretion and metabolism in man. J. Clin. Endocrinol. Metab., 83(5):1806-9, 1998.

Aslam, M. N.; Paruchuri, T.; Bhagavathula, N. \& Varani, J. A mineral-rich red algae extract inhibits polyp formation and inflammation in the gastrointestinal tract of mice on a high-fat diet. Integr. Cancer Ther., 9(1):93-9, 2010.

Auvinen, H. E.; Romijn, J. A.; Biermasz, N. R.; Pijl, H.; Havekes, L. M.; Smit, J. W.; Rensen, P.C. \& Pereira, A. M. The effects of high fat diet on the basal activity of the hypothalamus-pituitary-adrenal axis in mice. J. Endocrinol., 214(2):191-7, 2012.

Björntorp, P. \& Rosmond, R. Obesity and cortisol. Nutrition, 16(10):92436, 2000.

Björntorp, P. Do stress reactions cause abdominal obesity and comorbidities? Obes. Rev., 2(2):73-86, 2001.

Ble-Castillo, J. L.; Aparicio-Trapala, M. A.; Juárez-Rojop, I. E.; TorresLopez, J. E.; Mendez, J. D.; Aguilar-Mariscal, H.; Olvera-Hernández, V.; Palma-Cordova, L. C. \& Diaz-Zagoya, J. C. Differential effects of high-carbohydrate and high-fat diet composition on metabolic control and insulin resistance in normal rats. Int. J. Environ. Res. Public Health, 9(5):1663-76, 2012.

Bose, M.; Oliván, B. \& Laferrère, B. Stress and obesity: the role of the hypothalamic-pituitary-adrenal axis in metabolic disease. Curr. Opin. Endocrinol. Diabetes Obes., 16(5):340-6, 2009.

Bravo, E.; Palleschi, S.; Aspichueta, P.; Buqué, X.; Rossi, B.; Cano, A.; Napolitano, M.; Ochoa, B. \& Botham, K. M. High fat diet-induced non alcoholic fatty liver disease in rats is associated with hyperhomocysteinemia caused by down regulation of the transsulphuration pathway. Lipids Health Dis., 10:60, 2011.

Bray, G. A. Medical consequences of obesity. J. Clin. Endocrinol. Metab., 89(6):2583-9, 2004.

Chakraborty, T. R.; Donthireddy, L.; Adhikary, D. \& Chakraborty, S. Longterm high fat diet has a profound effect on body weight, hormone levels, and estrous cycle in mice. Med. Sci. Monit., 22:1601-8, 2016.

Desbriere, R.; Vuaroqueaux, V.; Achard, V.; Boullu-Ciocca, S.; Labuhn, M.; Dutour, A. \& Grino, M. 11beta-hydroxysteroid dehydrogenase type 1 mRNA is increased in both visceral and subcutaneous adipose tissue of obese patients. Obesity (Silver Spring), 14(5):794-8, 2006.

Glass, A. R.; Burman, K. D.; Dahms, W. T. \& Boehm, T. M. Endocrine function in human obesity. Metabolism, 30(1):89-104, 1981.

Gundersen, H. J. G. Notes on the estimation of the numerical density of arbitrary profiles: The edge effect. J. Microsc., 111(2):219-23, 1977.

Hautanen, A. \& Adlercreutz, H. Altered adrenocorticotropin and cortisol secretion in abdominal obesity: implications for the insulin resistance syndrome. J. Intern. Med., 234(5):461-9, 1993.

Herberg, L. \& Kley, H. K. Adrenal function and the effect of a high-fat diet on C57BL/6J and C57BL/6J-ob/ob mice. Horm. Metab. Res., 7(5):410$5,1975$.

Incollingo Rodriguez, A. C.; Epel, E. S.; White, M. L.; Standen, E. C.; Seckl, J. R. \& Tomiyama, A. J. Hypothalamic-pituitary-adrenal axis dysregulation and cortisol activity in obesity: A systematic review. Psychoneuroendocrinology, 62:301-18, 2015.

Jiang, T.; Wang, Z.; Proctor, G.; Moskowitz, S.; Liebman, S. E.; Rogers, T.; Lucia, M. S.; Li, J. \& Levi, M. Diet-induced obesity in C57BL/6J mice causes increased renal lipid accumulation and glomerulosclerosis via a sterol regulatory element-binding protein-1c-dependent pathway. J. Biol. Chem., 280(37):32317-25, 2005.

Kim, K. A.; Gu, W.; Lee, I. A., Joh, E- H. \& Kim, D. H. High fat dietinduced gut microbiota exacerbates inflammation and obesity in mice via the TLR4 signaling pathway. PLoS One, 7(10):e47713, 2012.

Kopelman, P. G. Obesity as a medical problem. Nature, 404(6778):63543, 2000.

Kumari, M.; Chandola, T.; Brunner, E. \& Kivimaki, M. A nonlinear relationship of generalized and central obesity with diurnal cortisol secretion in the Whitehall II study. J. Clin. Endocrinol. Metab., 95(9):4415-23, 2010.

Kyrou, I. \& Tsigos, C. Stress hormones: physiological stress and regulation of metabolism. Curr. Opin. Pharmacol., 9(6):787-93, 2009.

Livingstone, D. E.; Jones, G. C.; Smith, K.; Jamieson, P. M.; Andrew, R.; Kenyon, C. J. \& Walker, B. R. Understanding the role of glucocorticoids in obesity: tissue-specific alterations of corticosterone metabolism in obese Zucker rats. Endocrinology, 141(2):560-3, 2000.

Ljung, T.; Andersson, B.; Bengtsson, B. A.; Björntorp, P. \& Màrin, P. Inhibition of cortisol secretion by dexamethasone in relation to body fat distribution: a dose-response study. Obes. Res., 4(3):277-82, 1996. 
Lottenberg, S. A.; Giannella-Neto, D.; Derendorf, H.; Rocha, M.; Bosco, A.; Carvalho, S. V.; Moretti, A. E.; Lerário, A. C. \& Wajchenberg, B. L. Effect of fat distribution on the pharmacokinetics of cortisol in obesity. Int. J. Clin. Pharmacol. Ther., 36(9):501-5, 1998.

Mandarim-de-Lacerda, C. A. Métodos Quantitativos em Morfología. Rio de Janeiro, EDUERJ, 1995.

Mokrani, Z.; Soltani, Y. \& Hadj Bekkouche, F. Visceral obesity induced by a high-calorie diet leads to dyslipidemia, insulin resistance and impairs adrenal function in male rabbits. In: World Rabbit Science Association. Proceedings 10th World Rabbit Congress, September 3-6. Sharm ElSheikh, World Rabbit Science Association, 2012. pp.1213-8.

National Research Council (U. S.) Committee for the Update of the Guide for the Care and Use of Laboratory Animals. Guide for the Care and Use of Laboratory Animals. 8th ed. Washington (D. C.), The National Academies Press, 2011.

Navarrete, J.; Vásquez, B. \& del Sol, M. Morphoquantitative analysis of the Ileum of C57BL/6 mice (Mus musculus) fed with a high-fat diet. Int. J. Clin. Exp. Pathol., 8(11):14649-57, 2015.

Paulsen, S. K.; Pedersen, S. B.; Fisker, S. \& Richelsen, B. 11Beta-HSD type 1 expression in human adipose tissue: impact of gender, obesity, and fat localization. Obesity (Silver Spring),15(8):1954-60, 2007.

Peckett, A. J.; Wright, D. C. \& Riddell, M. C. The effects of glucocorticoids on adipose tissue lipid metabolism. Metabolism, 60(11):1500-10, 2011.

Pratchayasakul, W.; Kerdphoo, S.; Petsophonsakul, P.; Pongchaidecha, A.; Chattipakorn, N. \& Chattipakorn, S. C. Effects of high-fat diet on insulin receptor function in rat hippocampus and the level of neuronal corticosterone. Life Sci., 88(13-14):619-27, 2011.

Rask, E.; Walker, B. R.; Söderberg, S.; Livingstone, D. E.; Eliasson, M.; Johnson, O.; Andrew, R. \& Olsson, T. Tissue-specific changes in peripheral cortisol metabolism in obese women: increased adipose 11 beta-hydroxysteroid dehydrogenase type 1 activity. J. Clin. Endocrinol. Metab., 87(7):3330-6, 2002.

Reeves, P. G.; Nielsen, F. H. \& Fahey, G. C. Jr. AIN-93 purified diets for laboratory rodents: final report of the American Institute of Nutrition ad hoc writing committee on the reformulation of the AIN-76A rodent diet. J. Nutr., 123(11):1939-51, 1993.

Rosmond, R.; Holm, G. \& Björntorp, P. Food-induced cortisol secretion in relation to anthropometric, metabolic and haemodynamic variables in men. Int. J. Obes. Relat. Metab. Disord., 24(4):416-22, 2000.

Samuelsson, A. M.; Matthews, P. A.; Argenton, M.; Christie, M. R.; McConnell, J. M.; Jansen, E. H.; Piersma, A. H.; Ozanne, S. E.; Twinn, D. F.; Remacle, C.; Rowlerson, A.; Poston, L. \& Taylor, P. D. Dietinduced obesity in female mice leads to offspring hyperphagia, adiposity, hypertension, and insulin resistance: a novel murine model of developmental programming. Hypertension, 51(2):383-92, 2008.

Stimson, R. H.; Andersson, J.; Andrew, R.; Redhead, D. N.; Karpe, F.; Hayes, P. C.; Olsson, T. \& Walker, B. R. Cortisol release from adipose tissue by 11 beta-hydroxysteroid dehydrogenase type 1 in humans. Diabetes, 58(1):46-53, 2009.

Stimson, R. H.; Andrew, R.; McAvoy, N. C.; Tripathi, D.; Hayes, P. C. \& Walker, B. R. Increased whole-body and sustained liver cortisol regeneration by 11 beta-hydroxysteroid dehydrogenase type 1 in obese men with type 2 diabetes provides a target for enzyme inhibition. Diabetes, 60(3):720-5, 2011.

Stomby, A.; Andrew, R.; Walker, B. R. \& Olsson, T. Tissue-specific dysregulation of cortisol regeneration by $11 \mathrm{bHSD} 1$ in obesity: has it promised too much? Diabetologia, 57(6):1100-10, 2014.

Strain, G. W.; Zumoff, B.; Strain, J. J.; Levin, J. \& Fukushima, D. K. Cortisol production in obesity. Metabolism, 29(10):980-5, 1980.

Swierczynska, M. M.; Mateska, I.; Peitzsch, M.; Bornstein, S. R.; Chavakis, T.; Eisenhofer, G.; Lamounier-Zepter, V. \& Eaton, S. Changes in morphology and function of adrenal cortex in mice fed a high-fat diet. Int. J. Obes (Lond.), 39(2):321-30, 2015.

World Health Organization (WHO). Obesity and Overweight. Geneva, World Health Organization, 2017. Available from: http://www.who.int/ news-room/fact-sheets/detail/obesity-and-overweight
Yang, N.; Ying, C.; Xu, M.; Zuo, X.; Ye, X.; Liu, L.; Nara, Y. \& Sun, X. High-fat diet up-regulates caveolin-1 expression in aorta of diet-induced obese but not in diet-resistant rats. Cardiovasc. Res., 76(1):167-74, 2007.

\author{
Corresponding author: \\ Cristian Sandoval \\ Universidad de La Frontera \\ Facultad de Odontología \\ Avenida Francisco Salazar 01145 \\ Casilla 54-D \\ Temuco \\ CHILE
}

\section{E-mail: cristian.sandoval@ufrontera.cl}

Received: 18-01-2018

Accepted: 23-03-2018 